\title{
Hybrid phytoremediation: an ultimate bio-solution for leachate
}

\author{
RoyChoudhury A. ${ }^{{ }^{*}}$, Singh N. ${ }^{1}$ and Veeraraghavan A. ${ }^{2}$ \\ ${ }^{1}$ Ramky Advanced Centre for Environmental Research, Ramky Enviro Engineers Ltd., Hyderabad, 500032, India \\ ${ }^{2}$ Department of Civil Engineering, Annamalai University, Annamalai Nagar, Tamil Nadu, 608002, India \\ Received: 22/06/2019, Accepted: 16/01/2020, Available online: 19/03/2020 \\ *to whom all correspondence should be addressed: e-mail: atunroy.choudhury@ramky.com
} https://doi.org/10.30955/gnj.003167

\section{Graphical abstract}

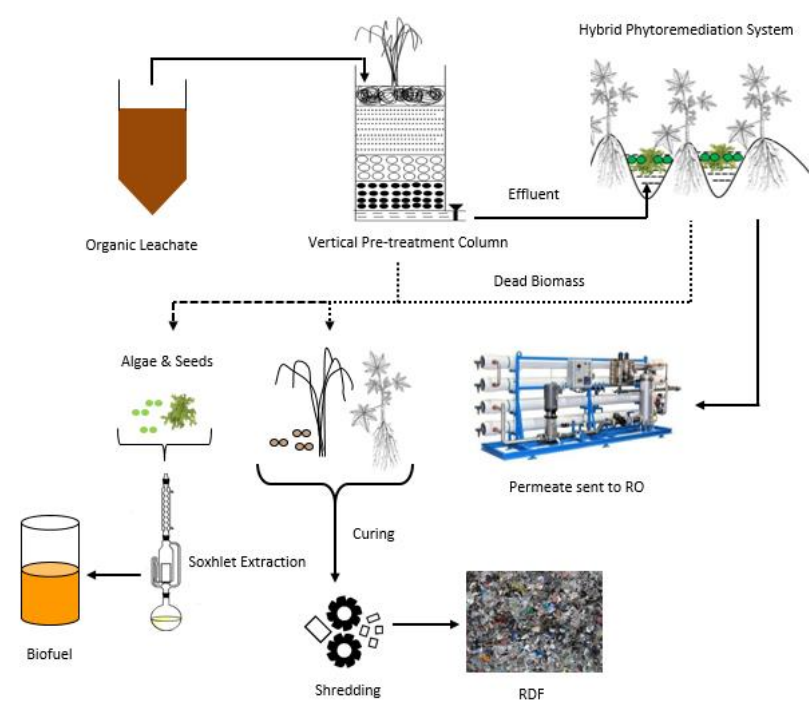

\section{Abstract}

In the recent era, utmost attention is paid towards exploring the alternative source of energies, being more specific green energies. In modern days, when growing energy scarcity is a hot topic and considered as a global threat, in that context a green technology capable of sustainably addressing waste management issues and synthesize waste-derived end-product such bio-diesel from Jatropha Curcas linnaeus (JCL) and Chlorella vulgaris shall be paid ancillary attention. The attribution of the abovementioned species and Lemnagibba $L$ towards the purification of the municipal solid waste (MSW) leachate by utilizing its bioaccumulation properties and ultimately yielding several value-added co-products could be the solution of the era in terms of sustainable leachate treatment. A specially designed ridge furrow phytoremediation wetland was fabricated under the controlled environment associated with a pre-treatment facility and bottom lining system to captivate the downward percolation. A $1.5 \mathrm{~m}$ high Jatropha species were planted at an interval of $1 \mathrm{~m}$ on the ridges and the root for the same found to reach a depth of $0.8 \mathrm{~m}$ on an average over a period of 3 months. Leachate was supplied by means of free flow into the furrows with an initial addition rate of
$1 \mathrm{~m}^{3}$ per day for a $10 \mathrm{~m} \times 10 \mathrm{~m}$ remediation hybrid pond system and simultaneously the loading was elevated up to $80 \mathrm{~m}^{3} / \mathrm{ha}$ /day. Prior to the active remediation zone, a pretreatment unit was installed which works on the bioaccumulation property of the vetiver grass (Chrysopogon zizanioides). A packed bed system of gravel, marble chips, sand, and coconut coir as a medium of filtration was installed to bring the concentrate waste juice up to the wetland treatment standard. Moreover, the bleaching influence of the sunlight also found to be effective against pathogen removal, active evaporation, and evapotranspiration. The ultimate treatment capacity for the designated size was assessed as $\sim 0.03 \mathrm{~m}^{3}$ per day ascertained with an HRT value of 45 days. The ultimate outcome was on par with the influent characteristics obligatory for the tertiary units with a comprehensive efficacy value evaluated as approx. $60 \%$. Thus, it's quite evident to claim the feasibility of the present study towards the bioremediation of the enormous quantity of leachate generation associated with the handling of solid waste which is otherwise, a costly affair.

Keywords: Bioaccumulation, biofuel, Chlorella vulgaris, jatropha, leachate, phytoremediation, vetiver grass, duckweed.

\section{Introduction}

Leachate is an unavoidable phenomenon associated with solid waste management. More the level of moisture present in the waste greater is the leachate generation. At present physicochemical treatment is the only existing option for leachate handling. Although, in terms of the cost consideration the method seeks a huge consumption of energy and eventually yielding secondary pollutants which is further a big headache for the safe disposal and ultimately ends up in landfills. Thus, a wholesome treatment facility capable of addressing issues attributed with leachate treatment in an eco-friendly way is the need of the era and the idea of synthesizing waste derived coproducts from the same platform provoked the present research. The selection of Jatropha, microalgae, and duckweed as a potential agent for the same was influenced by a couple of its frugal characteristics such as drought resistance, perenniality, bioaccumulation etc. (Abidin et al., 2011; Raouf et al., 2012; Landesman et al., 2005). Jatropha 
belongs to a family named, Euphorbiaceae. Basically, this species is independent to the fertility of the soil and previously explored by the several researchers towards the reclamation of the brownfields (Abidin et al., 2011; Abidin et al., 2017). Furthermore, various species of jatropha also has been commercially cultivated as a biofuel crop (Fawzy and Romagnoli, 2016; Daud et al., 2014; Sudsakorn et al., 2017). The seeds of this economically viable crop species serve as the substrate for the production of high-quality bio-fuel. The variety found to be also potentially effective against the leachate treatment and acts as a bio-coagulant (Abidin et al., 2011; Abidin et al., 2017). Whereas, algae, a eukaryote belongs to Chlorophyta division and Chlorellales family. Algae can be easily cultivated on a wide range of mediums such as wastewater, brackish water, leachate etc. (Ezea et al., 2018;). When algae are grown over typical waste streams then it helps to absorb the impurities as the nutrient for body growth and reduces the waste load (Satpal and Khambete, 2016). The same mechanism is replicated by the duckweed as well. The harvesting technique is also quite simple and inexpensive in the case of smaller constructed wetland system (Mackenzie et al., 2003; Daud et al., 2018). Approximately $70 \%$ of the atmospheric oxygen gets generated due to the autotrophic activity of the microalgae. The bioaccumulation property of microalgae both in acidic and alkaline $\mathrm{pH}$ range under aerobic environment makes it one of the most pertinent species of preference for leachate treatment (Raouf et al., 2012). On the other hand, though the ability of vetiver grass has been investigated in domestic wastewater treatment by several researchers, the behaviour of the species is quite unexplored while subjecting it to the raw leachate through a hybrid purification system (Darajeh et al., 2014; Maharjan and Pradhanang, 2017). Thus, the present study tried to identify the existing knowledge breach in terms of leachate management and address the same with optimum precision possible.

The major objective of the study was to explore the feasibility of Jatropha, algae, and duckweed profusely in MSW leachate treatment through a ridge and furrow hybrid purification system and yield waste-derived product such as biofuel by means of seed and algal digestion. Additionally, the study also aimed to find the most pertinent pre-treatment to eliminate the shock loading and ascertain the theory of eco-friendly management with optimum reusability.

\section{Materials and method}

The study involves critical and toxic pollutants and hence mishandling of the same may cause catastrophe to the local environment and surrounding. Therefore, an unassailable designing and execution were of basal need. The pre-requisite involved a set of operation starting from soil selection to proof of concept development at the bench scale and henceforth filed implementation. The comprehensive research work was conducted within the premises of Hyderabad Integrated Municipal Solid Waste Ltd. (HiMSW Ltd.). All the raw ingredients, equipment/instruments, and machinery required for the study were solely provided by the HiMSW Ltd., Jawahar
Nagar. The entire operational process flow is illustrated below.

\subsection{Land attainment}

A pertinent blending of target soil and stabilized organic wastes manure was utterly crucial for the nutritive and supportive growth requirement for the plants. The preliminary criterion behind the selection of the apposite class of soil was the permeability to ensure minimal infiltration. Thus, two distinctive varieties were selected for ridge and furrow based on the field exigency. The soil variety preferred for the ridge was of sandy loam category with a mix ratio of 1:1 with the organic MSW city compost to optimize the porosity, ensure better growth for the plant species, and facilitate optimal bio-adsorption. Albeit, the furrow soil was more of clayey in nature with the diminutive permeability value of approx. $7 \times 10^{-7} \mathrm{~cm} / \mathrm{s}$ to captivate downward percolation. A distance of $1 \mathrm{~m}$ was maintained amidst successive ridges to ensure free-flow. The height of each ridge was designed and ascertained as $0.8 \mathrm{~m}$ depending on the root length of the plant species. Furthermore, the influent height was restricted to $0.5 \mathrm{~m}$ to abstain any possibilities of overflow or spillage. Subjected to the dimensions of the wetland (i.e. $10 \mathrm{~m} \times 10 \mathrm{~m}$ ) a total number of 9 ridges were accommodated within the horizontal span. Hence the derivable number of furrows is 7. Each furrow was facilitated with individual outlet. Based on the information gathered through the extensive literature survey an average of $1.5 \mathrm{~m}$ high Jatropha $\mathrm{Sp}$. was chosen for the experimental purpose to facilitate superlative adsorption capabilities. Green algae and duckweed were kept in a suspended manner within the furrow to obstruct the free-flow and support other crucial purposes. A cross-sectional overview of the fabricated system has been rendered in Figure 1.

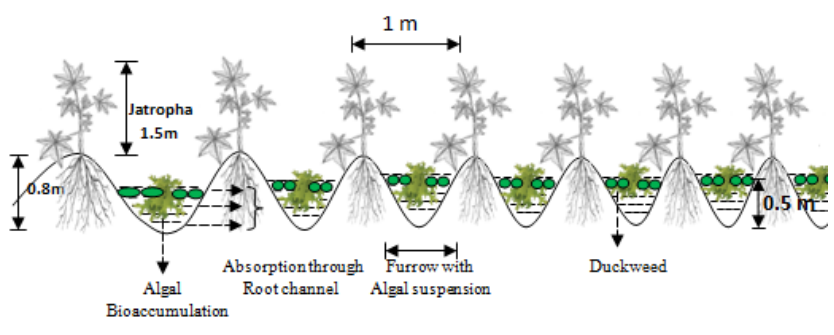

Figure 1. Phytoremediation set-up

\subsection{Preparation of the filter media}

Owing to the elevated concentration of the MSW leachate it's quite mandatory to prostrate the same to the treatability levels for the phytoremediation system. Hence a pre-treatment mechanism was commissioned with biophysical treatment mechanism. Vetiver grass has opted as the admissible species based on the dexterity of bioaccumulation, root length, and growth tenure. Contingent on the trial and error mechanism the entire working column length was decided as $5.5 \mathrm{~m}$ attributed to the optimization of organic loading rate (OLR) and hydraulic retention time (HRT), out of which top $0.5 \mathrm{~m}$ was densely packed coconut coir layer, successively followed by 
a layer of coarse and fine sand (particle size ranging between $0.5 \mathrm{~mm}-4.75 \mathrm{~mm}$ ). The bottom layer of $1 \mathrm{~m}$ height was fabricated of gravel and amid a layer of marble chips were incorporated which rages approx. $1.5 \mathrm{~m}$ of vertical elevation. The column system is depicted in Figure 2.

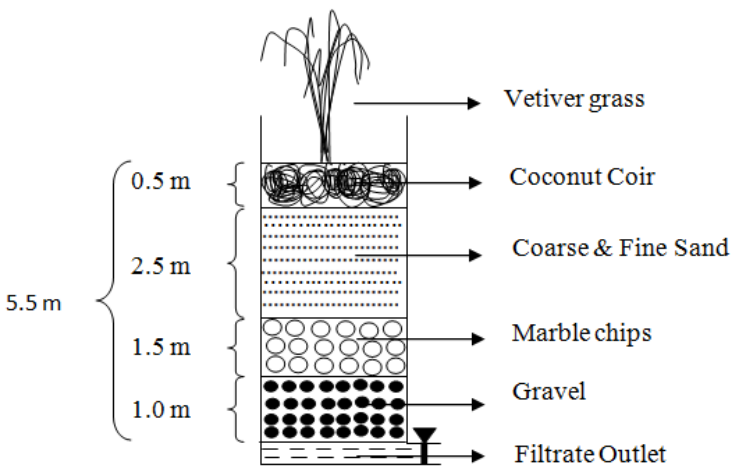

Figure 2. Pre-treatment column

\subsection{RDF quality enhancement}

Once the life period of the plant Sp. such as Vetiver and Jatropha were over the same was replaced with a new species and the old one has been subjected to Micronization through shredding and mixing with Refuse derived fuel, segregated from MSW. Both the sp. poses very minute moisture and hence the addition of the same in regular RDF given a value addition in terms of quality. The similar end-use has opted for the duckweed as well. Once the duckweed crossed its life period, the same was dried by means of atmospheric curing and disposed of with RDF for reuse.

\subsection{Biofuel extraction}

Once the seeds started appearing in Jatropha plants the same has been disembodied and dried with the help of Table 1. Soil characteristics

\begin{tabular}{|c|c|c|c|c|}
\hline \multirow{2}{*}{ Parameter } & \multirow{2}{*}{ Unit } & \multicolumn{3}{|c|}{ Results } \\
\hline & & LTP* sample & Buffer sample & SEP sample \\
\hline Texture & - & & Sandy loam & \\
\hline Color & - & Grey & Brown & Light Brown \\
\hline $\mathrm{pH}$ & - & 6.7 & 6.9 & 7.3 \\
\hline $\mathrm{EC}$ & $\mu \mathrm{s} / \mathrm{cm}$ & 190 & 188 & 158 \\
\hline Organic carbon & $\%$ & 1.16 & 1.02 & 0.61 \\
\hline Bulk density & $\mathrm{gr} / \mathrm{cc}$ & 1.34 & 1.51 & 1.44 \\
\hline Calcium as $\mathrm{Ca}$ & $\mathrm{mg} / \mathrm{kg}$ & 3687 & 3266 & 2493 \\
\hline Magnesium as Mg & $\mathrm{mg} / \mathrm{kg}$ & 1280 & 1058 & 997 \\
\hline Sodium as $\mathrm{Na}$ & $\mathrm{mg} / \mathrm{kg}$ & 970 & 926 & 609 \\
\hline Avail. potassium & $\mathrm{mg} / \mathrm{kg}$ & 202 & 164 & 62 \\
\hline Avail. nitrogen & $\mathrm{mg} / \mathrm{kg}$ & 84 & 54 & 65 \\
\hline Avail. phosphorous & $\mathrm{mg} / \mathrm{kg}$ & 4.2 & 3.6 & 3.5 \\
\hline
\end{tabular}

*Leachate treatment plant

\subsection{Efficacy of the pre-treatment system}

As demonstrated in Figure 2 the pre-treatment mechanism was a vertical column, fabricated with different layers of purification media. Each layer was meant to address some specific pollutant and substances are illustrated as follows. The top coconut coir layer was meant for the removal of sunbath curing over a period of $48 \mathrm{~h}$. Later the same was crushed and transformed into the powder for the consecutive operations. The crushed seed of the Jatropha and the dried \& grinded algal biomass were coupled together and subjected to organic extraction with the help of $n$-Hexane for the synthesis of substantial biofuel. The extractable was first stowed within the thimble and the extraction procedure was continued for a period of $1.5 \mathrm{~h}$ to affirm complete retrieval. After the process got ended both the liquids were mutilated with the help of separation funnel. Due to the higher density and viscosity value of the biofuel, the same got deposited at the bottom of the funnel after subjecting it to the constant shaking followed by recess.

\section{Results}

The values obtained through the analytical studies of the influent and effluent concentrations for various parameters explicitly depicted the significance of the present study. The results are presented and established with proper discussion in the section illustrated below.

\subsection{Characteristics of the soil}

The initial preference was to utilize the locally available soil to minimize the expenditure. Thus, three different soil samples were collected from three distinct locations following the standard procedure. The first sample was collected beneath the leachate sump to maximize the probability of minimum soil permeability along with the presence of leachate tolerant microbial species. The second sample was more of a natural soil from the buffer zone area of the facility. Whereas the third sample was procured from the nearby area of the solar evaporation pond (SEP). The full-length characteristics of all three specimens are showcased in Table 1. the coarse suspended solids (SS) and also biochemical oxygen demand (BOD), Chemical oxygen demand (COD), Ammoniacal Nitrogen, and total organic carbon (TOC) up to certain extent (i.e. the average reduction of approx. 5-7\% is applicable to all the above parameters). The next layer of coarse and fine sand serves as a bio-physical filtration unit 
because of the presence of indigenous microorganism species within the pores. The major two target parameters of interest for the prior-mentioned layer are turbidity and phosphate $\left(\mathrm{PO}_{4}{ }^{3-}\right)$. The optimum phosphate depreciation capacity of the sand layer is analysed as $\sim 2.0 \mathrm{mg} / \mathrm{g}$. Contrarily the primary objective of the incorporated marble chips layer was to remove excessive sulphate from the influent. It has been observed that the layer is capable of handling and removal of an optimal sulphate $\left(\mathrm{SO}_{4}{ }^{2-}\right)$ concentration of approx. $5.2 \mathrm{mg} / \mathrm{g}$. The bottom media of coarse gravel was dedicated to incarcerate the movement of salt sediments, formed due to the higher concentration of the dissolved solids (TDS). Ultimately, vetiver grass was Table 2. Characteristics of the raw and pre-treated effluent rooted to the gravel layer to minimise the infiltration velocity, removal of the certain pollutants like phosphorus, heavy metals, and withhold the different layers together. An ancillary value-addition was obtained for the incorporation of the aforementioned grass species in the form of leachate odour minimization due to the unique capability of its roots of releasing a pleasant aroma. It has been observed during the study that slower infiltration rate influences a positive impact over the treatment efficacy. The overall performance of the pre-treatment column is further discussed in Table 2.

\begin{tabular}{|c|c|c|c|c|}
\hline \multirow{2}{*}{ Parameter* } & \multirow{2}{*}{ Unit } & \multicolumn{3}{|c|}{ Results } \\
\hline & & Raw leachate & Pre-treated effluent & Percentage reduction \\
\hline $\mathrm{pH}$ & - & $8.31 \pm 0.38$ & $6.92 \pm 0.25$ & 17 \\
\hline Phenolic compounds & $\mathrm{mg} / \mathrm{L}$ & $<1.0$ & $<1.0$ & - \\
\hline Arsenic & $\mathrm{mg} / \mathrm{L}$ & $0.26 \pm 0.04$ & $<0.20$ & 27 \\
\hline Lead & $\mathrm{mg} / \mathrm{L}$ & $0.17 \pm 0.03$ & $0.12 \pm 0.03$ & 29 \\
\hline Cadmium & $\mathrm{mg} / \mathrm{L}$ & $<0.1$ & $<0.1$ & - \\
\hline Hexavalent chromium & $\mathrm{mg} / \mathrm{L}$ & $<0.1$ & $<0.10$ & - \\
\hline Copper & $\mathrm{mg} / \mathrm{L}$ & $0.18 \pm 0.08$ & $0.130 \pm 0.04$ & 28 \\
\hline Nickel & $\mathrm{mg} / \mathrm{L}$ & $0.26 \pm 0.07$ & $0.22 \pm 0.06$ & 15 \\
\hline Mercury & $\mathrm{mg} / \mathrm{L}$ & $<0.1$ & $<0.1$ & - \\
\hline Zinc & $\mathrm{mg} / \mathrm{L}$ & $<0.5$ & $<0.5$ & - \\
\hline Fluoride & $\mathrm{mg} / \mathrm{L}$ & $1.9 \pm 0.35$ & $1.4 \pm 0.28$ & 26 \\
\hline Ammonical nitrogen & $\mathrm{mg} / \mathrm{L}$ & $884 \pm 73$ & $519.8 \pm 56.0$ & 41 \\
\hline Chlorides & $\mathrm{mg} / \mathrm{L}$ & $10260 \pm 216.4$ & $6560 \pm 142.6$ & 36 \\
\hline Sulfates & $\mathrm{mg} / \mathrm{L}$ & $470 \pm 22.5$ & $280 \pm 16.8$ & 40 \\
\hline Phosphorus & $\mathrm{mg} / \mathrm{L}$ & $262 \pm 12.3$ & $187 \pm 10.2$ & 29 \\
\hline TSS & $\mathrm{mg} / \mathrm{L}$ & $992 \pm 78.3$ & $377 \pm 19.6$ & 62 \\
\hline TDS & $\mathrm{mg} / \mathrm{L}$ & $27916 \pm 456.0$ & $20566 \pm 265.0$ & 26 \\
\hline COD & $\mathrm{mg} / \mathrm{L}$ & $14588 \pm 584.6$ & $8570 \pm 420.5$ & 41 \\
\hline BOD & $\mathrm{mg} / \mathrm{L}$ & $4668 \pm 304.2$ & $2650 \pm 154.9$ & 43 \\
\hline Oil and grease & $\mathrm{mg} / \mathrm{L}$ & $26 \pm 1.6$ & $14 \pm 0.9$ & 46 \\
\hline Total hardness & $\mathrm{mg} / \mathrm{L}$ & $1240 \pm 95.7$ & $720 \pm 88.7$ & 42 \\
\hline Alkalinity as $\mathrm{CaCO}_{3}$ & $\mathrm{mg} / \mathrm{L}$ & $4100 \pm 212.0$ & $2380 \pm 189.0$ & 42 \\
\hline
\end{tabular}

*Except BOD, all the parameters were analysed as per APHA standard method

The showcased data revealed that the pre-treatment unit is quite effective in the removal of TSS, COD, BOD, ammoniacal nitrogen, oil and grease, alkalinity, and hardness. Whereas, a moderate performance has been observed in the case of addressing the heavy metal toxicity. The overall performance was evaluated as a roughly $35 \%$ reduction in the gross pollutant concentration level, which is quite satisfactory for a pre-treatment unit. Although, the efficacy is predominantly relying on the rate of influent addition and the same has been optimized as $\sim 21 \mathrm{ml} / \mathrm{min}$. The treated effluent was pumped with the help peristaltic pump and uniformly spread over the constructed wetland.

\subsection{Optimization of experimental parameters}

The efficiency of the overall process majorly depends on the flow rate, OLR, and HRT. If excessive flow enters the system, subsequently the treatment capability will get depleted. Therefore, optimization of the major parameters is of utmost importance to provide a better quality of effluent. Based on the set of trails conducted the OLR has been optimized as approx. $80 \mathrm{~m}^{3} / \mathrm{ha}$ /day with an associated HRT value of 45 days, subjected to climatic conditions. Based on the total design area (i.e. $100 \mathrm{~m}^{2}$ ) and actual holding capacity of $6.125 \mathrm{~m}^{3}$, the leachate can be accommodated into the active remediation zone up to 205 days without any disturbance at the regular flow addition rate of $\sim 0.03 \mathrm{~m}^{3}$ per day. Once the primary parameters get optimized the secondary aim was to ensure maximum treatability and hence monitoring of certain significant parameters got mandatory which includes $\mathrm{pH}$, incoming and outgoing phosphorus, and $\mathrm{DO}$. $\mathrm{pH}$ and $\mathrm{DO}$ value are correlated with each other and needs to vary inversely proportionally as any change in aerobic to the anoxic condition will immediately lower the DO concentration and higher the $\mathrm{pH}$. Thus, the same was used for the crossvalidation of the monitoring parameters and evaluate the performance of the system. Furthermore, the concentration level of phosphorus projects the functionality of the biological treatment unit.

\subsection{Treated effluent}


The effluent from the pre-treatment column was further pumped and introduced to the hybrid wetland through open channel flow system for the further purification. The primary treatment agents in wetland encompass plant spices such as Jatropha, microalgae, duckweed, and native micro-organism sp. Each of the aforementioned agents has significant potential to address certain pollutants and the same has been discussed henceforth. Jatropha sp. has been found to be effective against the turbidity and COD removal, whereas, micro algae effectively removed BOD, nitrogen, phosphorus, total coliforms, and heavy metals. Ancillary fulcrum was allocated in the form of duckweed to ensure further purification and additional removal of ammonia from the waste stream. All the purification agents were so selected that legitimate symbiotism can be developed between them throughout the treatment tenure and would be capable to address a wide range of pollutants. The ultimate effluent quality generated from the wetland is illustrated in Table 3.

Table 3. Characteristics of the final effluent

\begin{tabular}{|c|c|c|c|c|}
\hline \multirow{2}{*}{ Parameter* } & \multirow{2}{*}{ Unit } & \multicolumn{3}{|c|}{ Results } \\
\hline & & Raw leachate & Final effluent & Percentage reduction \\
\hline $\mathrm{pH}$ & - & $8.31 \pm 0.38$ & $6.57 \pm 0.23$ & 21 \\
\hline Phenolic compounds & $\mathrm{mg} / \mathrm{L}$ & $<1.0$ & $<1.0$ & - \\
\hline Arsenic & $\mathrm{mg} / \mathrm{L}$ & $0.26 \pm 0.04$ & $<0.2$ & 31 \\
\hline Lead & $\mathrm{mg} / \mathrm{L}$ & $0.17 \pm 0.03$ & $<0.1$ & 47 \\
\hline Cadmium & $\mathrm{mg} / \mathrm{L}$ & $<0.1$ & $<0.1$ & - \\
\hline Hexavalent chromium & $\mathrm{mg} / \mathrm{L}$ & $<0.1$ & $<0.1$ & - \\
\hline Copper & $\mathrm{mg} / \mathrm{L}$ & $0.18 \pm 0.08$ & $<0.1$ & 50 \\
\hline Nickel & $\mathrm{mg} / \mathrm{L}$ & $0.26 \pm 0.07$ & $<0.2$ & 31 \\
\hline Mercury & $\mathrm{mg} / \mathrm{L}$ & $<0.1$ & $<0.1$ & - \\
\hline Zinc & $\mathrm{mg} / \mathrm{L}$ & $<0.5$ & $<0.5$ & - \\
\hline Fluoride & $\mathrm{mg} / \mathrm{L}$ & $1.9 \pm 0.35$ & $<1.0$ & 55 \\
\hline Ammonical nitrogen & $\mathrm{mg} / \mathrm{L}$ & $884 \pm 73$ & $78.2 \pm 10.3$ & 91 \\
\hline Chlorides & $\mathrm{mg} / \mathrm{L}$ & $10260 \pm 216.4$ & $3780 \pm 111.0$ & 63 \\
\hline Sulfates & $\mathrm{mg} / \mathrm{L}$ & $470 \pm 22.5$ & $89 \pm 9.5$ & 81 \\
\hline Phosphorus & $\mathrm{mg} / \mathrm{L}$ & $262 \pm 12.3$ & $54 \pm 7.8$ & 79 \\
\hline TSS & $\mathrm{mg} / \mathrm{L}$ & $992 \pm 78.3$ & $123 \pm 15.6$ & 88 \\
\hline TDS & $\mathrm{mg} / \mathrm{L}$ & $27916 \pm 456.0$ & $12487 \pm 211.3$ & 55 \\
\hline COD & $\mathrm{mg} / \mathrm{L}$ & $14588 \pm 584.6$ & $4600 \pm 202.1$ & 41 \\
\hline BOD & $\mathrm{mg} / \mathrm{L}$ & $4668 \pm 304.2$ & $1142 \pm 112$ & 68 \\
\hline Oil and grease & $\mathrm{mg} / \mathrm{L}$ & $26 \pm 1.6$ & $<10$ & 66 \\
\hline Total hardness & $\mathrm{mg} / \mathrm{L}$ & $1240 \pm 95.7$ & $265 \pm 20.5$ & 79 \\
\hline Alkalinity as $\mathrm{CaCO}_{3}$ & $\mathrm{mg} / \mathrm{L}$ & $4100 \pm 212.0$ & $1540 \pm 84.0$ & 62 \\
\hline
\end{tabular}

${ }^{*}$ Except BOD, all the parameters were analysed as per APHA standard method

The antecedent results portrayed in Table 3 explicitly unveils that the hybrid treatment system is quite efficient in the removal of the persistent pollutants from the waste stream. Other than the previous it is also capable of addressing predominant biological pollutants (i.e. nutrients) such as ammoniacal nitrogen, sulphates, phosphates, BOD \& COD, oil and grease etc. Concurrently, it can also successfully address inert solids based on the joint mechanism of lining material (clay), microorganisms, and bio-absorption of aqueous species. The ultimate filtration capacity was observed as around $60 \%$ on the basis of the average of all the target pollutants. Figure 3 and 4 delineates the variations in the level of major pollutant during pre and post-treatment period. The entire wetland operation was performed in the open atmospheric conditions and thus, the climatic influence was one of the crucial factors which played a significant impact over the effluent quality. The wetland was operated over the tenure of one year (i.e. Jan'18 to December'18) and the results of pre \& post-monsoon studies were as follows (Figure 5):

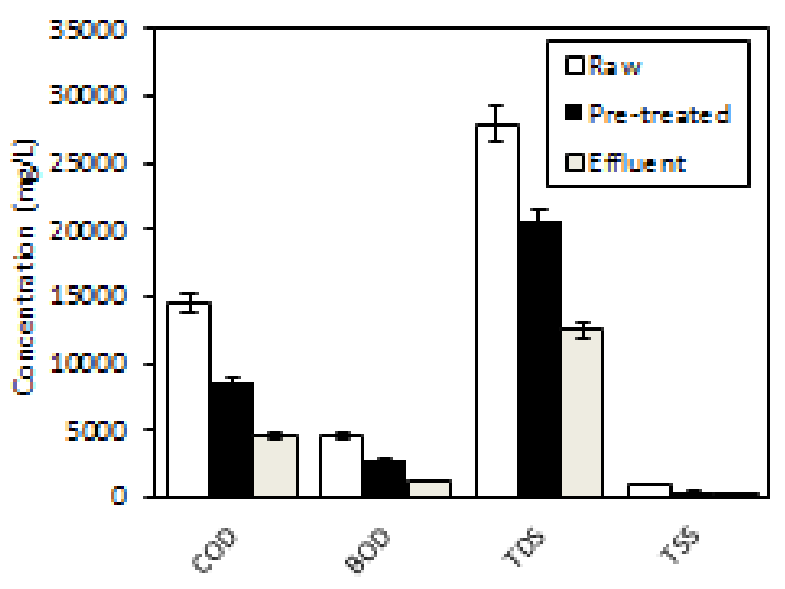

Figure 3. Treatment vs. reduction in concentration

Pre-monsoon (Jan'18-May'18): During this period the influent concentration was moderately higher. The average ambient temperature was recorded as $34.6{ }^{\circ} \mathrm{C}$. Due to the mesophilic range of temperature microbial 
activity flourished during the pre-monsoon period and so the treatment efficiency. An overall removal efficacy of 64 $\%$ was observed, attributed to a $\mathrm{COD} \& \mathrm{NH}_{3}-\mathrm{N}$ reduction of $45 \%$ and $93 \%$ respectively.

Post-monsoon (August'18-December'18): Due to the depleted temperature (i.e. average temperature: $24.37^{\circ} \mathrm{C}$ ), this season is a major challenge in terms of handling biological treatment units. Microorganisms sometimes went in the dormant stage during the night hours. The level of DO found to be curtailed near to $7 \mathrm{mg} / \mathrm{L}$, so resulting in the reduced overall treatment efficiency of approx. 57.3\%. Simultaneously, $\mathrm{COD}$ and $\mathrm{NH}_{3}-\mathrm{N}$ reduction values got declined to $38 \%$ and $88 \%$ respectively.

\subsection{Testing of leachability}

The raw influent contained persistent pollutant such as lead, cadmium, hexavalent chromium, copper, nickel, mercury, zinc, fluoride etc. in a moderate range. But, once the treatment tenure got over the ultimate effluent didn't record any trace of heavy metals in it. The same got removed through the bio-accumulation property of algae, vetiver grass, and duckweed. Thus, prior to utilizing them towards other frugal endues its mandatory to ensure zero Leachability of any toxic metals. Toxic characteristics leaching procedure (TCLP) test equipment from Airmech engineers was utilized to investigate the same. Once the active life period of the above-mentioned species got

Table 4. Leachability characteristics finished, the same was exposed to sunbath curing and successively followed by crushing. The crushed powder was homogeneously blended together and utilized towards the preparation of solution for TCLP. The test results for the same are enclosed in Table 4.

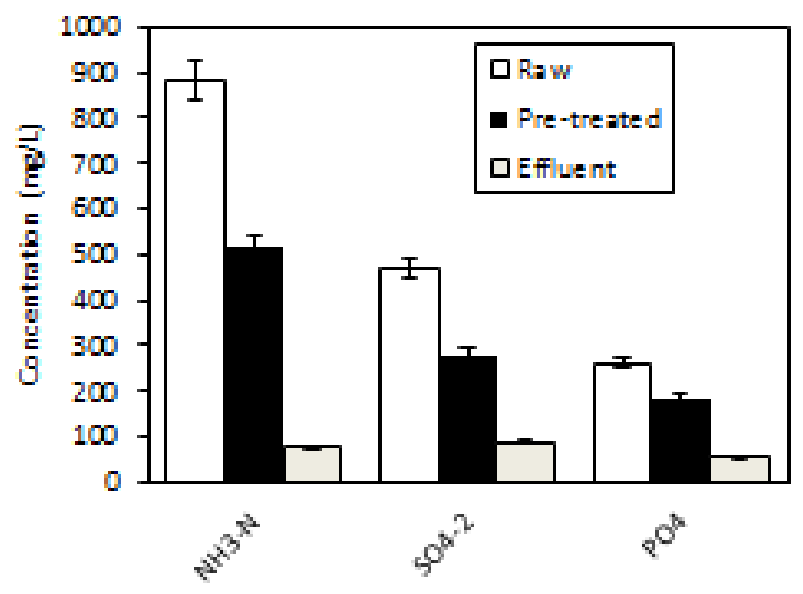

Figure 4. Treatment vs. reduction in concentration

\begin{tabular}{ccccc}
\hline Parameter & Unit & Method & Result & Concentration limit \\
\hline Arsenic (TCLP) & $\mathrm{mg} / \mathrm{L}$ & APHA 3120B & $<0.1$ & 5.0 \\
\hline Lead (TCLP) & $\mathrm{mg} / \mathrm{L}$ & APHA 3120B & 0.11 & 5.0 \\
\hline Cadmium (TCLP) & $\mathrm{mg} / \mathrm{L}$ & APHA 3120B & $<0.1$ & 1.0 \\
\hline Hexavalent chromium (TCLP) & $\mathrm{mg} / \mathrm{L}$ & APHA 3120B & $<0.2$ & 5.0 \\
\hline Copper (TCLP) & $\mathrm{mg} / \mathrm{L}$ & APHA 3120B & 0.35 & 25 \\
\hline Nickel (TCLP) & $\mathrm{mg} / \mathrm{L}$ & APHA 3120B & $<1.0$ & 20 \\
\hline Mercury (TCLP) & $\mu \mathrm{g} / \mathrm{L}$ & SW 846 7470 A & $<0.1$ & 0.2 \\
\hline Zinc (TCLP) & $\mathrm{mg} / \mathrm{L}$ & APHA 3120B & 11.77 & 250 \\
\hline
\end{tabular}

\section{*U.S. EPA. 1994}

The conclusion obtained from that above data is interpreted as minimum Leachability for all the toxic metals. Though the value is slightly higher in the case of zinc and copper, but still well within the permissible limits and hence the concern is nullified. Minimum Leachability also ensures the further usage of the aforementioned species towards other end applications.

\subsection{Assessment of groundwater quality}

Despite necessary preventive measures were taken to captivate outright downward percolation, due to the sensitivity of the research work a comprehensive groundwater analysis study has been carried out both in pre and post-monsoon session to ensure zero infiltration and figure out the seasonal influences. Four numbers of boreholes with each $36.5 \mathrm{~m}$ depth were constructed at four different corners of the wetland to withdraw the representative samples. The observations were recorded, averaged, and embossed in Table 5.

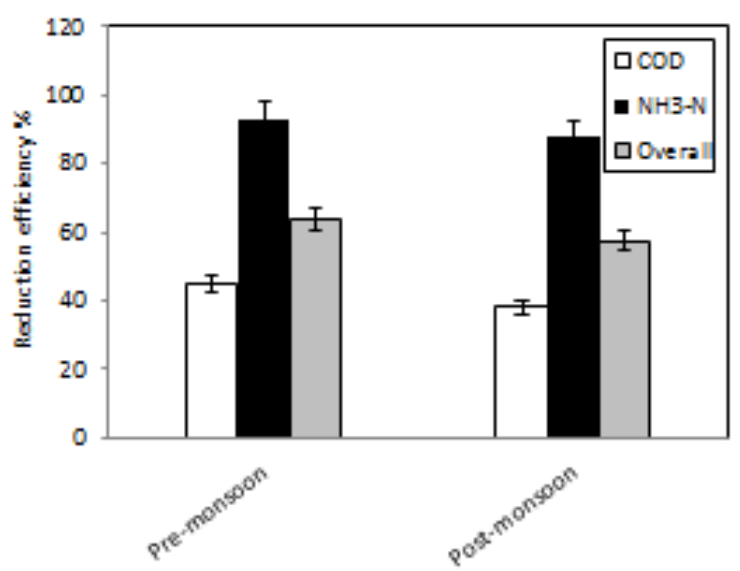

Figure 5. Climate vs. reduction efficiency 
Table 5. Groundwater quality analysis report

\begin{tabular}{|c|c|c|c|}
\hline \multirow{2}{*}{ Parameter* } & \multirow{2}{*}{ Unit } & \multicolumn{2}{|c|}{ Result } \\
\hline & & Pre-monsoon & Post-monsoon \\
\hline $\mathrm{pH}$ & - & $7.62 \pm 0.3$ & $7.12 \pm 0.25$ \\
\hline Phenolic compounds & $\mathrm{mg} / \mathrm{L}$ & $<1.0$ & $<1.0$ \\
\hline Arsenic & $\mathrm{mg} / \mathrm{L}$ & $<0.2$ & $<0.2$ \\
\hline Lead & $\mathrm{mg} / \mathrm{L}$ & $<0.1$ & $0.18 \pm 0.02$ \\
\hline Cadmium & $\mathrm{mg} / \mathrm{L}$ & $<0.1$ & $<0.1$ \\
\hline Hexavalent chromium & $\mathrm{mg} / \mathrm{L}$ & $<0.1$ & $<0.1$ \\
\hline Calcium & $\mathrm{mg} / \mathrm{L}$ & 156 & 268 \\
\hline Copper & $\mathrm{mg} / \mathrm{L}$ & $0.16 \pm 0.02$ & $0.32 \pm 0.03$ \\
\hline Nickel & $\mathrm{mg} / \mathrm{L}$ & $<0.2$ & $<0.2$ \\
\hline Zinc & $\mathrm{mg} / \mathrm{L}$ & $<0.5$ & 0.59 \\
\hline Fluoride & $\mathrm{mg} / \mathrm{L}$ & $1.12 \pm 0.1$ & $1.18 \pm 0.1$ \\
\hline Chlorides & $\mathrm{mg} / \mathrm{L}$ & $492 \pm 6$ & $852 \pm 5$ \\
\hline Sulphates & $\mathrm{mg} / \mathrm{L}$ & $44 \pm 2$ & $112 \pm 3$ \\
\hline TDS & $\mathrm{mg} / \mathrm{L}$ & $1540 \pm 84$ & $1988 \pm 65$ \\
\hline Oil and grease & $\mathrm{mg} / \mathrm{L}$ & $<10$ & $<10$ \\
\hline Total hardness & $\mathrm{mg} / \mathrm{L}$ & $596 \pm 55$ & $916 \pm 48$ \\
\hline Alkalinity as $\mathrm{CaCO}_{3}$ & $\mathrm{mg} / \mathrm{L}$ & $186 \pm 14$ & $372 \pm 14$ \\
\hline
\end{tabular}

*Standard APHA methods were followed for the analysis

It can be clearly observed due to the precipitation influences post-monsoon period eventually portrayed quite higher concentration of the majority of the parameters. Parameters such as calcium, copper, fluoride, chloride, and sulphate showed significantly lower concentration during the pre-monsoon period and the same trend can be also observed in the case of TDS, hardness, and alkalinity. All the parameter values lie well within the drinking water limit prescribed by IS 10500 : 2012, except calcium and total hardness. Therefore, in order to reveal the possible reason behind the elevated figures for the prior-mentioned parameters, an aquifer study was conducted. The study disclosed that the aquifer majorly consists of sedimentary rocks with a higher percentage of calcium salts and the same causing the higher values of alkalinity. Furthermore, the fact got established that the research work has no significant detrimental impact over the local groundwater quality.

\subsection{Biofuel assessment}

Once the extraction and separation got over, the same was analysed to discern the quality of the final output. Unlike the ordinary diesel, biofuel obtained from the mixed consortium exhibited more of green tint colour variation possibly due to the origin material. Whereas, other mandatory parameters such as total base number, gross calorific value, density, viscosity etc. were analysed as per the standard ASTM method and found to be satisfactory (Table 6).

Table 6. Biofuel analysis report

\begin{tabular}{cccc}
\hline Parameter & Unit & Result & ASTM $^{*}$ standard \\
\hline Gross Calorific Value & $\mathrm{cal} / \mathrm{gm}$ & $9532 \pm 210$ & - \\
\hline Flash point & ${ }^{0} \mathrm{C}$ & $152 \pm 3$ & 100 (Min) \\
\hline Solidification point & ${ }^{0} \mathrm{C}$ & $-13 \pm 2$ & -15 \\
\hline Total Base number & $\mathrm{mg} \mathrm{KOH} / \mathrm{gm}$ & $3.22 \pm 0.3$ & $2-5$ \\
\hline Viscosity & $\mathrm{mm}^{2} / \mathrm{s}$ & $4.8 \pm 0.35$ & $3.5-5.0$ \\
\hline Density & $\mathrm{kg} / \mathrm{L}$ & $0.859 \pm 0.2$ & $0.84-0.90$ \\
\hline
\end{tabular}

*American society for testing and materials

The prior-mentioned values clearly establish the potential of the derived fluid (yield rate: $87.2 \%$ by the raw weight of the material) as an alternate fuel resource. The same has been blended with ordinary diesel at a ratio of 1:9 (B10) and tested with internal combustion (IC) engine to evaluate the compatibility. The engine was chosen out of default because biofuel is only compatible with those engines whose ignition technology is based on compression. The test results were extremely successful in terms of output of the engine and mechanical efficacy. A minute depletion of approx. $0.05 \%$ and $0.1 \%$ have been observed in the case of output and efficiency respectively after three successive trails with a break load value of $100 \mathrm{~N}$ and the radius of break arm was adjusted to $0.35 \mathrm{~m}$.

\section{Discussion}

The utilization of Jatropha species towards the purification of certain primary pollutant such as turbidity, COD etc. is a 
well-proven fact and the potential is explored and supported by multiple preceding researchers (Abidin et al., 2011; Abidin et al., 2017). But unfortunately, there is no concrete evidence of investigation on the perusal of the aforementioned species in order to decontaminate MSW leachate. That is possibly due to the higher pollutant concentration of the liquor mass (Tomar and Agarwal, 2013). The same researchers also reported a long-term exposure can cause detrimental influences such as minute reduction in the growth rate, which includes mutations like smaller height of the plant, reduced biomass, decreased leaf area etc. Therefore, the present study tried to conquer the issue with the help of introducing a pre-treatment unit and the procedure is justified with quite a similar sort of the mechanism adopted by Kadaverugu et al., 2016 and Mackenzie et al., 2003. Furthermore, in order to enhance the functionality of the overall system a specific grass species named, vetiver was incorporated into the conventional system. It not only improved the quality of the treated effluent but also improved the aesthetics and an ancillary reduction of $15-20 \%$ in the pollution concentration level was achieved (Mathew et al., 2015; Boonsong and Chansiri, 2008). But, again the similar kind of deficiency of studies was observed when the scenario comes to the leachate treatment. Researchers like Darajeh et al., 2014; Maharjan and Pradhanang, 2017; Lishenga et al., 2015; Akpah et al., 201; Seroja et al., 2018 have extensively researched and discussed the potential of vetiver in domestic and industrial wastewater treatment, but nobody addressed the consequences of introducing the species to the direct leachate augmentation. The study overcame the same difficulty with the help of producing a hybrid system which almost instantly reacted to the introduction of the waste mass and collectively addressed different pollutants. Kadaverugu et al., 2013 also observed an almost equivalent rate of treatment as showcased in Table 2. A further hike of $2 \%$ has been noticed in the overall efficacy possibly due to the modification of the remediation species and the inclusion of coconut coir to ensure further removal. Once the concentration was brought down to the treatment limits of the wetland (i.e. COD < 10000 and TDS < 20000) then the same was introduced furrow by furrow in successive treatment tenure (Pei et al., 2016). Pie et al., 2016 also investigated about the climatic influences over the comprehensive removal and reported an efficacy value of $79.5 \%$ and $73.2 \%$ respectively for pre and post-monsoon period, which is significantly higher when compared with the obtained value. It's possibly due to the higher level of contaminated influent conditions when compared to the primary feedstock utilized for the prior-mentioned study. Here the individual impact of each agent can be further discussed to conclude over the functionality of each species. Eze et al., 2018; Satpal and Khambete, 2016 and Raouf et al., 2012 have collectively concluded an average nutrient removal efficacy as high as $75-95 \%$ and COD \& BOD removal potential of $45-60 \%$ which is absolutely on par with the present research work. Additionally, further purification was assured by the assimilation of duckweed. Mackenzie et al., 2003; Daud et al., 2018 have researched and reported the potential of the aforementioned species individually can reduce the total metal concentration levels up to $70 \%$ associated with a BOD, COD, $\mathrm{pH}, \mathrm{TSS}$, and TDS removal of around $45 \%, 40 \%, 15 \%, 35 \%$, and $40 \%$ respectively through the phytoremediation mechanism, which is good enough to stand alone. Despite, the present research work has recorded a significantly lower level of efficacy (i.e. approx. $21 \%$ ) from the aforementioned species that is probably due to the incorporation of raw pre-treated effluent without any dilution, unlike the other research studies. However, a minute depletion in the level of chlorophyll and lethargic rate of biomass production has been recorded once subjected to long term exposure (Landesman et al., 2005). Eventually, the yield and quality of the biofuel obtained at the end of the research tenure was subjected to validation and comparability. Research works individually explored the potential of Jatropha towards the synthesis of bio-oil and reported it can yield up to $45 \%-60 \%$ of oil when compared to the weight of the seeds (Fawzy and Romagnoli, 2016; Daud et al., 2014; Sudsakorn et al., 2017; Dutta and Mandal, 2014). Anyhow, the present study used a proportionate blend of 1:3 between Jatropha seeds and dried algal mass based on the field conditions, which also optimized the ultimate yield. Unlike Jatropha, approx. 9095\% of algal bio-oil is retractable (Dong et al., 2016; Ihsanullah et al., 2015) and thus the fusion of both yielded an ultimate output of approx. 87\% (Zaimes et al., 2015).

\section{Conclusion}

Despite several attempts by numerous researchers, bioremediation of MSW leachate has been miserably failed. Thus, the present study tried to exercise and demonstrate the best possible technique to excel the pertaining intellectual gap. Based on the results and pieces of evidence obtained the following conclusions were ascertained:

- A pre-treatment unit is mandatory to handle the concentrated waste liquor and ensure the success of the further treatment unit.

- The efficacy of the pre-treatment unit is subjected to the retention time and it was as high as $35 \%$.

- Vetiver was quite effective in terms of odour minimization and an optimum removal of 90 Threshold Odour Number (TON) (i.e. from 190 TON to 100 TON) was recorded for the trials conducted during the post-monsoon session.

- The ultimate effluent recorded a comprehensive efficacy of $60 \%$ with a paramount nutrient removal of $83.67 \%$.

- The final product was commensurate with the influent limits of the tertiary treatment and the same resulted in a preeminent efficiency from the advanced unit.

- Bio-sorption and microcellular trapping caused minimal bioassay and zero Leachability for all the treatment agents.

- The gross calorific value of RDF has been ameliorated from $2500 \mathrm{cal} / \mathrm{gm}$ to $3200 \mathrm{cal} / \mathrm{gm}$ with the help of the 
potential mixing (i.e. 9:1) of dried \& shredded discarded treatment agents.

- The synthesized biofuel performed satisfactorily with the IC engine when blended in the form of B10.

\section{Acknowledgements}

Authors wish to acknowledge the Ramky Enviro Engineers Ltd. for extending analytical facility and financial assistance.

\section{References}

Abidin Z.Z., Ismail N., Yunus R., Ahamad I.S. and Idris A. (2011), A preliminary study on Jatropha curcas as coagulant in wastewater treatment, Environmental Technology, 32(9), 971-977.

Abidin Z.Z., Madehi N. and Yunus R. (2017), Coagulative Behaviour of Jatropha curcas and its Performance in Wastewater Treatment, Environmental Progress \& Sustainable Energy, 36(6), 1709-1718. doi: 10.1002/ep. 12635.

Boonsong K. and Chansiri M. (2008), Domestic Wastewater Treatment using Vetiver Grass Cultivated with Floating Platform Technique, AU Journal of Technology, 12(2), 73-80.

Darajeh N., Idris A., Truong P., Aziz A.A., Bakar R.A. and CheMan H. (2014), Phytoremediation Potential of Vetiver System Technology for Improving the Quality of Palm Oil Mill Effluent, Advances in Materials Science and Engineering, 2014, Article ID 683579, 10 pages, doi: 10.1155/2014/ 683579.

Datta A. and Mandal B.K. (2014), Use of Jatropha Biodiesel as a Future Sustainable Fuel, Energy Technology \& Policy, 1(1), 814, doi: 10.1080/23317000.2014.930723.

Daud M.K., Ali S., Abbas Z., Zaheer I.E., Riaz M.A., Malik A., Hussain A., Rizwan M., Zia-ur-Rehman M. and Zhu S.J. (2018), Potential of Duckweed (Lemna minor) for the Phytoremediation of Landfill Leachate, Journal of Chemistry, 2018, Article ID 3951540, 9 pages, doi: 10.1155/2018/ 3951540.

Daud N.M., Abdullah S.R.S., Hasan H.A. and Yaakob Z. (2014), Production of biodiesel and its wastewater treatment technologies: A review, Process Safety and Environment Protection, 94, 487-508, doi: 10.1016/j.psep.2014.10.009.

Dong T., Knoshaug E.P., Davis R., Laurens L.M.L., VanWychen S., Pienkos P.T. and Nagle N. (2016), Combined algal processing: A novel integrated biorefinery process to produce algal biofuels and bioproducts, Algal Research, 19, 316-323, doi: 10.1016/j.algal.2015.12.021.

Ezea V.C., Velasquez-Ortaa S.B., Hernández-Garcíab A., MonjeRamírezb I. and Orta-Ledesmab M.T. (2018), Kinetic modelling of microalgae cultivation for wastewater treatment and carbon dioxide sequestration, Algal Research, 32, 131-141, doi: 10.1016/j.algal.2018.03.015.

Fawzy M.M. and Romagnoli F. (2016), Environmental Life cycle assessment for Jatropha Bio-diesel in Egypt. Editors. Riga Technical University, Institute of Energy Systems and Environment. Proceedings of the International Scientific conference "Environmental and Climate Technologies" 2015 October14-16, Riga, Lativia, Energy Procedia, 95, 124-131, doi: 10.1016/j.egypro.2016.09.033.
Ihsanullah, Shah S., Ayaz M., Ahmed I., Ali M., Ahmad N. and Ahmad I. (2015), Production of Biodiesel from Algae, Journal of Pure and Applied Microbiology, 9(1), 79-85.

Kadaverugu R., Shingare R.P., Raghunathan K., Juwarkar A.A., Thawale P.R. and Singh S.K. (2016), The role of Sand, Marble chips and Typha latifolia in domestic Wastewater Treatment - A Column Study on Constructed Wetlands, Environmental Technology, 37(19), 2508-2515, doi: 10.1080/09593330. 2016.1153156.

Landesman L., Parker N.C., Fedler C.B. and Konikoff M. (2005), Modeling duckweed growth in wastewater treatment systems, Livestock Research for Rural Development, 17(6).

Lishenga I.W., Nyaanga D.M., Owino J.O. and Wambua R.M. (2015), Efficacy of Hydroponic and Soil-Based Vetiver Systems in the Treatment of Domestic Wastewater, International Journal of Pure and Applied Sciences and Technology, 26(2), 53-63.

Mackenzie S.M., Waite S. and Metcalfe D.J. (2003), Landfill Leachate Ecotoxicity Experiments using Lemna minor, Water, Air, \& Soil Pollution: Focus, 3(3), 171-179, doi: 10.1023/A:1023973516564.

Maharjan A. and Pradhanang S. (2017), Potential of Vetiver Grass for Wastewater Treatment, Environment and Ecology Research, 5(7), 489-494, doi: 10.13189/eer.2017.050704.

Mathewa M., Rosaryb C., Sebastianc M. and Cheriand S.M. (2016), Effectiveness of Vetiver System for the Treatment of Wastewater from an Institutional Kitchen, Editors. ICETEST 2015. Proceedings of the International Conference on Emerging Trends in Engineering, Science and Technology; 2016 December 9-11; Kerala, India, Procedia Technology 24, 203-209, doi: 10.1016/j.protcy.2016.05.028.

Mathewa M., Rosaryb C., Sebastianc M. and Cheriand S.M. (2016), Effectiveness of Vetiver System for the Treatment of Wastewater from an Institutional Kitchen, Editors. ICETEST 2015, Proceedings of the International Conference on Emerging Trends in Engineering, Science and Technology, 2016 December 9-11; Kerala, India, Procedia Technology, 24, 203-209, doi: 10.1016/j.protcy.2016.05.028.

Pei H., Shao Y., Chanway C.P., Hu W., Meng P., Li Z., Chen Y. and Ma G. (2016), Bioaugmentation in a pilot-scale constructed wetland to treat domestic wastewater in summer and autumn, Environmental Science and Pollution Research International, 23(8), 7776-7785, doi: 10.1007/s11356-0155834-3.

Raouf N.A., Al-Homaidan A.A. and Ibraheem I.B.M. (2012), Microalgae and wastewater treatment, Saudi Journal of Biological Sciences, 19, 257-275, doi: 10.1016/j.sjbs.2012.04.005.

Satpal and Khambete A.K. (2016), Waste Water Treatment Using Micro-Algae - A review Paper, International Journal of Engineering Technology, Management and Applied Sciences, 4(2), 188-192.

Seroja R., Effendi H. and Hariyadi S. (2018), Tofu wastewater treatment using vetiver grass (Vetiveria zizanioides) and zeliac, Applied Water Science, 8(2), doi: 10.1007/s13201-0180640-y.

Sudsakorn K., Saiwuttikul S., Palitsakun S., Seubsai A. and Limtrakul J. (2017), Biodiesel Production from Jatropha Curcas Oil Using Strontium-doped $\mathrm{CaO} / \mathrm{MgO}$ Catalyst, Journal of 
Environmental Chemical Engineering, 5(3), 2845-2852, doi: 10.1016/j.jece.2017.05.033.

Tomar N.S. and Agarwal R.M. (2013), Influence of Treatment of Jatropha curcas L. Leachates and Potassium on Growth and Phytochemical Constituents of Wheat (Triticum aestivum L.), American Journal of Plant Sciences, 4, 1134-1150, doi: 10.4236/ajps.2013.45140 Published Online May 2013.

Yeboah S.A., Allotey M.A.N. and Biney E. (2015), Purification of Industrial Wastewater with Vetiver Grasses (Vetiveria Zizanioides): The Case of Food And Beverages Wastewater in Ghana, Asian Journal of Basic and Applied Sciences, 2(2), 114.

Zaimes G.G., Vora N., Chopra S.S., Landis A.E. and Khanna V. (2015), Design of Sustainable Biofuel Processes and Supply Chains: Challenges and Opportunities, Processes, 3, 634-663, doi: 10.3390/pr3030634. 